\title{
BRICS and Partnerships for Sustainable Development: Prospects for Trade With Least Developed Countries ${ }^{1,2}$
}

\author{
A. Morozkina, V. Skryabina
}

\begin{abstract}
Aleksandra Morozkina - PhD, Head of Structural Reforms Division; Associate Professor, Economic Expert Group; National Research University Higher School of Economics; 15/13 bldg. 5 Petrovka Ulitsa; E-mail: a.k.morozkina@gmail.com

Valentina Skryabina - PhD, Lead Advisor Analytical Center for the Government of the Russian Federation; National Research University Higher School of Economics, 13 bldg. 4 Myasnitskaya Ulitsa, Moscow, Russian Federation; E-mail: skryabina.valentina@gmail.com
\end{abstract}

\begin{abstract}
The informal BRICS group (Brazil, Russia, India, China and South Africa) is actively working to solve the most acute global problems. This is why opportunities for implementing the sustainable development goals (SDGs) at BRICS summits is a topic for urgent research. This article discusses the prospects for achieving SDG 17.11 by the least developed countries (LDCS) in the framework of mutual trade with BRICS. SDG 17.11, unlike other goals, was expected to be achieved in 2020, but World Trade Organization (WTO) estimates for 2019 showed that progress was too slow. Against the sharp drop in international trade in 2020 due to economic shutdowns, the implementation of this goal is especially high on the agenda. This article describes the current implementation of the SDG by BRICS. A general analysis of mutual trade between LDCs and BRICS shows the low involvement of least developed countries in trade with BRICS. The methodology for the study involves computations of two trade indices and the identification of new clusters of LDCs. The export propensity index and trade intensity index are calculated in order to identify the countries with the most promise to increase exports to BRICS. The authors selected 15 LDCs with prospects for trade development with BRICS - Angola, Democratic Republic of the Congo, Mozambique, Bangladesh, Guinea, Mauritania, Mali, Guinea-Bissau, Nepal, Tanzania, Zambia, Bhutan, Lesotho, Malawi and Solomon Islands. Among 32 other LDCs, the authors identify five clusters based on their economic structure, including the role played in their economies by official development assistance (ODA) and personal remittances. Clustering allows BRICS to provide targeted support to LDCs in order to increase their export potential through the most effective mechanisms for each economy.
\end{abstract}

Key words: Sustainable Development Goals; SDG 17; international trade; least developed countries; BRICS; trade indices

For citation: Morozkina A., Skryabina V. (2021). BRICS and Partnerships for Sustainable Development: Prospects for Trade with Least Developed Countries. International Organisations Research Journal, vol. 16, no 1, pp. 85-106 (in English). DOI: 10.17323/1996-7845-2021-01-04

${ }^{1}$ The editorial board received the article in November 2020.

${ }^{2}$ This work was prepared with the grant support of the Faculty of World Economy and International Affairs of the National Research University Higher School of Economics in 2021. 


\section{Introduction}

Sustainable development has been one of the main topics for discussion since the first meeting of the BRICS countries (Brazil, Russia, India, China and South Africa). In a joint statement by BRIC leaders, approved at the group's first formal summit in 2009 in Yekaterinburg, it was noted that "the implementation of the concept of sustainable development ... should be a major vector in the change of paradigm of economic development" [BRIC, 2009]. Later, BRICS reaffirmed its commitment to the implementation of the sustainable development goals (SDGs) adopted in 2015 [BRICS, 2016]. In 2020, during the period of Russia's presidency, dialogue on issues of international development cooperation was declared one of the main priorities [BRICS-Russia, 2020].

SDG goal 17 - to increase global partnership for sustainable development - brings together various aspects of international relations connected with the greater involvement of developing countries in global economic processes, including the least developed countries (LDCs). Taking into consideration the role of BRICS as a representative of developing countries, this goal deserves the utmost attention. It covers such areas as fulfilling commitments to provide development aid, mobilization of additional financial resources and stimulating investment in developing states, expanding cooperation in the fields of science and technology, and increasing the role of developing countries' exports in world trade.

The goal of increasing the share of exports from the LDCs, unlike other SDGs, was to be achieved by 2020, but World Trade Organization (WTO) estimates in 2018 indicated even then that progress was too slow. In 2018, the LDCs' share of world exports of goods and services was equal to $0.94 \%$, an increase of only $0.05 \%$ in comparison to $2015(0.89 \%)$ and less than the level in $2011(0.95 \%)$. According to international statistics, the LDCs' share of world exports amounted to only $1.03 \%$ in 2019, which clearly illustrates the unattainability of the task by 2020 under the current circumstances [ITC, n. d.]. Against the background of an expected sharp decrease in volumes of international trade of 13-32\% in 2020 [Azevêdo, 2020], the challenge of achieving this goal becomes particularly acute. At present, in fact, achievement of the goal depends not on the performance of the LDCs, but on how the decline in their exports will correlate with the decline in world exports. At the same time, the least developed countries, due to their low diversification of exports and dependence on the prices of export goods and the supplies of large economies, are more vulnerable to the increased uncertainty in world trade.

The lack of significant progress is associated with both insufficient measures to open the markets for goods from the LDCs [WTO, 2019], and the insufficiency of classical trade liberalization measures proposed by the developed countries and international organizations in general [Gay, 2018]. The latter can be explained by the existence of other more significant constraints to export growth, including production capacity, lack of infrastructure, distance, and political and social instability.

The contribution of BRICS countries and their possible actions aimed at the achievement of SDG 17.11 by the LDCs has not been explored in the academic literature. At the same time, the literature does point to the importance of BRICS' contribution to the implementation of the SDGs and the need to develop an alternative approach in the sphere of trade due to the ineffectiveness of the measures taken so far. Thus, this study suggests that BRICS, which positions itself as a source of expertise for emerging economies, can come up with new approaches to increase the involvement of LDCs in world trade.

The purpose of this article is to identify the potential areas for BRICS' cooperation related to support of exports from the least developed countries. To characterize the current state of the problem, it is first necessary to analyze the state of mutual trade between the LDCs and 
BRICS, which will help to identify the most promising LDCs for trade expansion. An assessment of the export propensity and trade intensity indices of LDCs with BRICS will help to draw conclusions about the potential for increasing LDCs' exports to BRICS. Clustering of LDCs based on economic indicators and the structure of the economy of these countries will help to identify other limitations and opportunities for the implementation of SDG 17.11, as well as to outline possible ways to support the development of exports from these countries.

\section{Literature Review}

BRICS' compliance with the SDGs is analyzed primarily in the framework of the voluntary national reviews (VNRs) provided by the United Nations (UN) members. In the surveys carried out by Brazil, India, Russia and South Africa, already provided to the UN, there is no data on the achievement of SDG 17.11 (an increase in the share of exports from the least developed countries) [Government of Brazil, 2017; Government of India, 2017; Government of Russia, 2020; Government of South Africa, 2019]. This may be related to two factors - the minimal progress toward achieving this goal and the lack of adequate statistics at the national level. China provided an overview in 2016, in the first year of the goals' realization process, which is why only the national sustainable development priorities were included. In 2017, the Ministry of Foreign Affairs of the People's Republic of China (PRC) released a progress report on the implementation of the SDGs, specifying the measures to reduce the restrictions on LDC access to Chinese markets [Government of China, 2017].

In the academic literature, quite a lot of attention is paid to the activities of BRICS in the field of sustainable development and also in the frameworks of trade relations, investment and provision of development assistance. N.G. Khmelevskaya noted that the cooperation of the five on sustainable development "is in line with the domestic economic priorities" [Khmelevskaya, 2018, p. 88] within the framework of foreign trade relations. The European Institute for Political, Social and Economic studies (EURISPES) emphasized that BRICS plays a significant role in world trade and finance and has already contributed to the involvement of some LDCs in global economic processes [Basile, Cecchi, 2019]. A.I. Svetlichnyi noted that the BRICS countries, taking into account their experience in the sphere of sustainable development, "are expected to make a significant contribution to the SDG program both in their countries and abroad" [2018, p. 82]. S.N. Bobylev and S.V. Solovyova concluded that Russia could play a significant role in the implementation of SDG 17 [2016, p. 37]. A.K. Morozkina demonstrated the importance of BRICS in complementing the traditional development assistance system with new approaches [2017]. At the same time, some studies arrived at the conclusion that the growth of exports from BRICS, especially those based on the use of cheap labour, is replacing existing and potential exports from less developed or smaller developing countries [Donno, Rudra, 2019]. In other studies, on the contrary, an increase in trade of China and India with developing states, including the African ones, was noted [Nowak, 2016].

A vast body of literature is devoted to the development of trade in the least developed countries and to the implementation of SDG 17, and in many contributions the need for alternative approaches is mentioned [Bellman, Tipping, 2015; Cornia, Scognamillo, 2016; Flento, Ponte, 2017; Gay, 2018; Reinert, 2009; UN, 2019]. As highlighted in the UN's review, trade expansion is mainly associated with less processed products, and 39 out of 47 countries are identified as dependent on commodity exports [UN, 2019]. Among the reasons given for low growth rates of trade from the LDCs, the following were mentioned: the lack of consensus within international organizations [Flento, Ponte, 2017]; strengthening of protectionist measures in world trade [Navarro-Pabsdorf, Martínez-Alcalá, Moral-Pajares, 2020]; and the deterioration 
of the terms of trade for exporters of raw materials, which are mainly LDCs [Sachs et al., 2020, p. 6], related to the 2020 quarantine measures. This UN report underlined the differences that exist among the least developed countries and points to the impossibility of applying universal measures to them [Cornia, Scognamillo, 2016]. Therefore, we propose a "clusterization" of the LDCs on the basis of three indicators - the presence of military conflict, the size of the population and the key sector of the economy. For each group a different set of measures to stimulate export is proposed.

\section{Trends in Trade and Economic Relations Between BRICS and LDCs}

The current condition of trade and economic relations between BRICS and LDCs is characterized by a marked increase in mutual trade. Since the establishment of BRICS, the trade turnover between the countries has grown close to 1.4 times, amounting to \$191.4 billion in 2019 . Repeating the global trend, LDC imports ( $\$ 123.8$ billion by 2019) from BRICS exceed exports ( $\$ 67.5$ billion) by $1.5-2$ times. Moreover, the dynamics of imports from BRICS is less volatile compared to the global flows - there are no drastic changes in volume in 2013-16. Generally, it can be noted that the value of both the growth of exports over imports and the increase in exports and imports of BRICS with LDCs is higher than the global average. This certainly reflects the importance of China, the largest trading partner for each of the least developed countries. The volume of trade with all BRICS countries is about $30-34 \%$ of the total trade turnover of the LDCs. Moreover, China's share is increasing; by 2019 it reached $75 \%$ of LDC exports to BRICS and $26 \%$ among all countries. BRICS imports are slightly more differentiated - China accounts for $65 \%$ of the total volume. India is also a significant trading partner for LDCs among BRICS countries, whose share of $17-18 \%$ in exports and $23-26 \%$ in imports is quite stable. At the same time, South Africa's indicators fell to $4 \%$ and $7 \%$, respectively.

Thus, assessing the overall trade indicators of BRICS countries and LDCs, we can note the indisputable dependence of LDCs on imports of goods from third countries, as well as the rather high importance of BRICS in the foreign trade turnover of the least developed countries, so that more than a third of trade is accounted for by the association. At the same time, the supply of goods occurs mainly with China and India, the importance of South Africa has significantly decreased, and trade with Russia and Brazil is negligible.

LDC exports are concentrated on mineral products: they account for $32 \%$ of the LDCs' trade with the world, and $63 \%$ of trade with BRICS. The least developed countries also supply light industry goods, ferrous and non-ferrous metals and some plant-based products (fruits, vegetables, cereals), among other items (Fig. 1).

The general characteristics of the foreign trade of the LDCs in the context of goods show a high dependence of the economies on the supply of mineral resources and goods with high added value, whereas the exports of these countries are naturally focused on products with a low level of recycling.

Thus, the overall analysis of the LDCs' foreign trade highlights the complexity of meeting the target set out in SDG 17.11. The trade trend of LDCs and BRICS is also not positive for achieving this goal, since the exports of LDCs are critically dependent on the sales of raw materials and resources.

The least developed countries are involved in foreign trade with BRICS countries in different ways. As for the interest in supplies to BRICS countries, there is a noticeable bias among the LDCs - more than $41 \%$ of total exports are accounted for by Angola, whose share in 2015 reached $47 \%$, followed by Myanmar (10\% of the total), the Democratic Republic of the Congo 


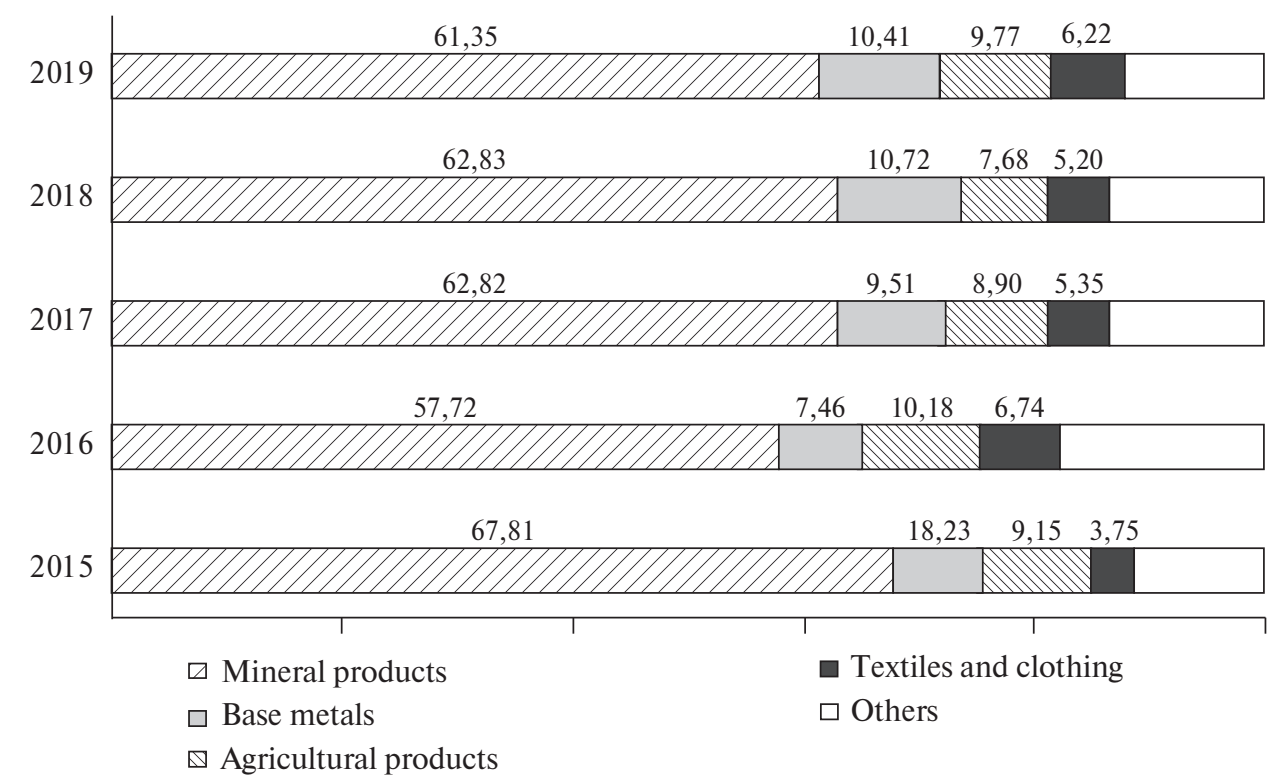

Fig. 1. Dynamics of Changes in the Structure of LDC Exports to BRICS, 2015-19

Source: Compiled by the authors based on data from the International Trade Center [n. d.].

(6.8\%), Bangladesh (6.8\%), Guinea (5.2\%) and Laos (4.5\%); the shares of 10 more countries Mozambique, Zambia, Cambodia, South Sudan, Tanzania, Sudan, Mauritania, Yemen and Nepal - exceed $1 \%$. The remaining 32 countries account for $10 \%$ of total exports. Thus, the existing trade relations of the LDCs are characterized by heterogeneity - four countries account for $64.5 \%$ of total exports to the countries of the world and $59.7 \%$ to BRICS countries, while the rest are involved in foreign trade to a much lesser extent. Taking into account the observed trend, the issue of achieving SDG 17 can be considered in two ways: by identifying opportunities for increasing exports by the main exporting countries of the group and by identifying the potential for increasing supplies by countries less involved in foreign trade.

\section{Assessment of the Potential for Export Growth From LDCs to BRICS}

In order to assess how to achieve the goal of increasing LDC exports, the trade potential of the LDCs and BRICS countries can be evaluated using trade indices. It is assumed that the conclusions drawn from the calculations of trade indices will make it possible to identify those LDCs for which the development of trade with BRICS will bring the greatest effect to the economies of the countries.

First, the LDC export propensity index ${ }^{3}$ [Mikic, Gilbert, 2009] is considered, which determines the share of exports in a country's gross domestic product (GDP) and characterizes

\footnotetext{
${ }^{3}$ The export propensity index is calculated using the following formula: $\frac{\sum_{s} X_{d s}}{G D P_{d}} \times 100$, $X_{d s}$ - export of the considered country to the partner country; GDPd - GDP of the considered country.
} 
the dependence of national producers on demand in foreign markets. ${ }^{4}$ The results of the calculation for all LDCs with the exception of Eritrea, Somalia and South Sudan ${ }^{5}$ are presented in Table 1.

Table 1. LDCs' Export Propensity Index to BRICS, 2018

\begin{tabular}{|l|c|l|c|l|c|}
\hline \multicolumn{1}{|c|}{ Country } & $\begin{array}{c}\text { Index } \\
\text { value, } \%\end{array}$ & \multicolumn{1}{|c|}{ Country } & $\begin{array}{c}\text { Index } \\
\text { value, } \%\end{array}$ & $\begin{array}{c}\text { Country } \\
\text { value, } \\
\%\end{array}$ \\
\hline Angola & 28.8 & Cambodia & 4.1 & Sierra Leone & 1.0 \\
Solomon Islands & 25.7 & Yemen & 3.4 & Niger & 0.4 \\
Guinea & 25.0 & Burkina Faso & 3.2 & Djibouti & 0.4 \\
Mozambique & 18.6 & Tanzania & 2.8 & Central African Republic & 0.3 \\
Democratic Republic & 12.4 & Sudan & 2.5 & Uganda & 0.3 \\
of the Congo & 12.3 & Madagascar & 2.4 & Ethiopia & 0.2 \\
Guinea-Bissau & 11.3 & Malawi & 2.3 & Burundi & 0.2 \\
Mauritania & 10.4 & Afghanistan & 2.1 & East Timor & 0.2 \\
Bhutan & 10.0 & Senegal & 1.8 & Rwanda \\
Lesotho & 9.3 & Benin & 1.8 & Kiribati & 0.2 \\
Laos & 8.3 & Vanuatu & 1.7 & Haiti & 0.2 \\
Mali & 8.1 & Nepal & 1.7 & Tuvalu & 0.1 \\
Myanmar & 7.5 & Togo & 1.5 & Gambia & 0.1 \\
Zambia & 7.2 & Comoros & 1.3 & Sao Tome and Principe & 0.002 \\
Liberia & 5.4 & Bangladesh & 1.1 & & 0.05 \\
Chad & & & &
\end{tabular}

Source: Authors' calculations based on data from the International Trade Center [n. d.].

The results of the calculation of the index indicate a fairly high interest in the exports of nine LDCs - Angola, Solomon Islands, Guinea, Mozambique, the Democratic Republic of the Congo, Guinea-Bissau, Mauritania, Bhutan and Lesotho - for which the index value exceeds $10 \%$. At the same time, a third of the countries have an index value of less than 1, which underlines the lack of interest of these states in developing trade relations with BRICS. For those LDCs with a fairly high index of propensity to export to BRICS countries, we can assume that there is a potential for export growth in the short term.

It can be noted that the index reveals the importance of supplies to BRICS countries as already significant exporters from the least developed countries (Angola, the Democratic Re-

${ }^{4}$ International trade statistics for some LDCs are published on official websites with a time lag. In order to maximize data coverage in the study, trade indices are calculated based on 2018 data.

${ }^{5}$ GDP data for 2018 are not available. 
public of the Congo, Guinea, Mozambique and Mauritania), and those countries that are not among the leaders in terms of exports (Solomon Islands, Lesotho, Bhutan and Guinea-Bissau).

Another important trade index that characterizes the foreign trade relations of states is the trade intensity index [Cornia, Scognamillo, 2016].${ }^{6}$ It can be used to determine the importance of mutual exports between the LDCs and BRICS in comparison with the global exports of the LDCs. The intensity index was calculated both for individual BRICS countries and for BRICS as a whole. In the latter case, extremely low results of trade intensity were obtained, which indicates that the export operations of BRICS countries and LDCs are directed to other countries, and also suggests more prospects for expanding trade relations between the LDCs and individual BRICS countries, rather than the association. The intensity index for each BRICS and LDC country is presented in Table 2.

Table 2. Index of Intensity of Trade of the LDCs and BRICS, 2018

\begin{tabular}{|l|c|c|c|c|c|}
\hline \multicolumn{1}{|c|}{ State } & Brazil & India & China & Russia & $\begin{array}{c}\text { South African } \\
\text { Republic }\end{array}$ \\
\hline Afghanistan & 0.007 & 0.164 & 0.003 & 0.022 & 0.002 \\
Angola & 0.219 & 0.541 & 0.107 & 0.009 & 2.254 \\
Bangladesh & 0.335 & 1.041 & 0.076 & 0.111 & 0.235 \\
Benin & 0.063 & 0.086 & 0.010 & 0.002 & 0.046 \\
Bhutan & 0.000 & 0.101 & 0.000 & 0.000 & 0.000 \\
Burkina Faso & 0.005 & 0.103 & 0.001 & 0.006 & 0.090 \\
Burundi & 0.000 & 0.007 & 0.000 & 0.002 & 0.009 \\
Cambodia & 0.012 & 0.032 & 0.030 & 0.009 & 0.033 \\
Central African Republic & 0.000 & 0.004 & 0.000 & 0.000 & 0.008 \\
Chad & 0.001 & 0.084 & 0.001 & 0.000 & 0.008 \\
Comoros & 0.002 & 0.007 & 0.000 & 0.000 & 0.010 \\
Democratic Republic of the Congo & 0.044 & 0.049 & 0.033 & 0.006 & 2.506 \\
Djibouti & 0.010 & 0.132 & 0.008 & 0.003 & 0.236 \\
Eritrea & 0.000 & 0.001 & 0.000 & 0.002 & 0.033 \\
Ethiopia & 0.011 & 0.115 & 0.012 & 0.017 & 0.151 \\
Gambia & 0.040 & 0.023 & 0.002 & 0.000 & 0.014 \\
Guinea & 0.018 & 0.061 & 0.006 & 0.011 & 0.179 \\
Guinea Bissau & 0.002 & 0.018 & 0.000 & 0.000 & 0.002 \\
Haiti & 0.020 & 0.013 & 0.003 & 0.002 & 0.006 \\
Kiribati & 0.000 & 0.000 & 0.000 & 0.000 & 0.000 \\
\hline
\end{tabular}

${ }^{6}$ The trade intensity index has the following formula for calculating: $\frac{\sum_{s d} X_{s d} / \sum_{s w} X_{s w}}{\sum_{w d} X_{w d} / \sum_{w y} X_{w y}}$, $X_{s d}-$ mutual exports of the countries under consideration; $X_{s w}-$ total exports of the countries under consideration; $X_{w d}-$ total world exports to the countries under consideration; $X_{w y}$ - world exports. 


\begin{tabular}{|c|c|c|c|c|c|}
\hline State & Brazil & India & China & Russia & $\begin{array}{l}\text { South African } \\
\text { Republic }\end{array}$ \\
\hline Laos & 0.001 & 0.025 & 0.013 & 0.027 & 0.001 \\
\hline Lesotho & 0.000 & 0.005 & 0.000 & 0.000 & 3.570 \\
\hline Liberia & 0.059 & 0.027 & 0.009 & 0.001 & 0.111 \\
\hline Madagascar & 0.009 & 0.045 & 0.005 & 0.004 & 0.679 \\
\hline Malawi & 0.003 & 0.030 & 0.001 & 0.006 & 1.218 \\
\hline Mali & 0.005 & 0.023 & 0.002 & 0.008 & 3.095 \\
\hline Mauritania & 0.019 & 0.018 & 0.008 & 0.030 & 0.084 \\
\hline Mozambique & 0.019 & 0.336 & 0.010 & 0.018 & 8.125 \\
\hline Myanmar & 0.017 & 0.253 & 0.071 & 0.049 & 0.021 \\
\hline Nepal & 0.001 & 1.176 & 0.005 & 0.002 & 0.009 \\
\hline Niger & 0.013 & 0.017 & 0.001 & 0.000 & 0.007 \\
\hline Rwanda & 0.000 & 0.020 & 0.001 & 0.006 & 0.126 \\
\hline Sao Tome and Principe & 0.001 & 0.000 & 0.000 & 0.000 & 0.001 \\
\hline Senegal & 0.045 & 0.145 & 0.010 & 0.101 & 0.284 \\
\hline Sierra Leone & 0.017 & 0.016 & 0.001 & 0.000 & 0.109 \\
\hline Solomon Islands & 0.000 & 0.005 & 0.002 & 0.000 & 0.002 \\
\hline Somalia & 0.027 & 0.070 & 0.003 & 0.001 & 0.029 \\
\hline South Sudan & 0.000 & 0.001 & 0.007 & 0.001 & 0.002 \\
\hline Sudan & 0.007 & 0.135 & 0.012 & 0.093 & 0.091 \\
\hline Tanzania & 0.008 & 0.289 & 0.017 & 0.035 & 1.060 \\
\hline East Timor & 0.004 & 0.001 & 0.001 & 0.000 & 0.001 \\
\hline Togo & 0.033 & 0.064 & 0.009 & 0.035 & 0.129 \\
\hline Tuvalu & 0.000 & 0.000 & 0.000 & 0.000 & 0.001 \\
\hline Uganda & 0.003 & 0.092 & 0.003 & 0.013 & 0.378 \\
\hline Vanuatu & 0.000 & 0.000 & 0.000 & 0.000 & 0.000 \\
\hline Yemen & $\mathrm{n} / \mathrm{a}$ & 0.100 & 0.008 & 0.055 & 0.140 \\
\hline Zambia & 0.003 & 0.077 & 0.010 & 0.001 & 5.719 \\
\hline
\end{tabular}

Source: Authors' calculations based on UN data [n. d.].

The higher the value of the index, the more intensive the trade relations between countries are when compared to their trade relations with the rest of the world. Just as Brazil and Russia are involved in foreign trade with LDCs, the intensity index with them is less than 1 . It can therefore be concluded that there are no close trade links and thus no expressed prospects for export expansion. This is also the trend of the LDCs' most important partner, China, because of its trade orientation with the U.S., Europe and Asia. India, the second most important trading partner of the LDCs, had an index value of over 1, with two countries, Bangladesh and Nepal, having territorial proximity and historical trade links. The intensity index of South Africa shows eight LDCs with relatively closer trade links; in descending order, these are: Mozambique, Zambia, Lesotho, Mali, Democratic Republic of the Congo, Angola, Tanzania and 
Malawi. Thus, the trade intensity index identified countries with a relatively high potential for trade growth, such as Lesotho and Malawi.

In summary, an analysis of the foreign trade relations of BRICS and LDC countries highlights the rather weak involvement of LDCs in the supply of goods to BRICS, with two countries accounting for half of the 47 countries (Angola and Myanmar). The structure of supply focuses on raw materials and minerals, as well as fruit and vegetables, which, in order to meet the LDC export target, 17.11 SDGs call for increased resource extraction and increased agricultural production. The trade indices identify LDCs that are export-oriented to the BRICS countries and also identify several countries for which trade is intense with India and South Africa.

\section{Clustering of LDCs}

An analysis of the prospects for increased exports from LDCs to BRICS and the implementation of SDG 17.11 shows that BRICS countries have a direct interest in the exports of only a few of the least developed countries. Significant obstacles to export development are, of course, both external trade constraints and domestic economic performance.

The least developed countries are heterogeneous in their economic structure and export potential, both to BRICS countries and to the rest of the world, so a universal approach is not acceptable. Some LDCs already have export-building potential, such as Bangladesh; some need support for nascent export production - for example, Senegal plans to begin oil production in 2023. At the same time, some LDCs, such as Sao Tome and Principe, cannot increase or diversify their exports because of their small populations or remoteness from major markets, which significantly increases the cost of their exports. Therefore, in order to identify priority measures to support the exports of least developed countries, the countries are first divided into two groups - those with export growth potential to BRICS countries and those that require an alternative approach (Table 3).

In the case of LDCs with export growth prospects in BRICS countries, an analysis of the external trade relations of LDCs and BRICS countries makes it possible to divide the least developed countries into three categories based on the degree of increase in the relative prospects for trade linkages. The first category includes countries with currently high levels of exports to BRICS (relative to other LDC countries), as well as high values on both indices. Angola, the Democratic Republic of the Congo and Mozambique are in this group. In Table 3, these countries are listed in column 15, with three criteria: their share of exports to BRICS is above $1 \%$, the value of the trade intensity index is above 10, and the value of the export propensity index to any BRICS country is above 1 . The second category includes countries with relatively significant exports to BRICS and a high score on one of the calculated indexes: Bangladesh, Guinea, Tanzania, Mali, Mauritania, Zambia. In column 15 of Table 3 these states have a number 2; their share of exports to BRICS is above $1 \%$ and either the value of the trade intensity index is above 10 or the value of the export propensity index to any BRICS country is above 1 . The third category includes states highlighted by indices but with relatively low present levels of supply to BRICS: Solomon Islands, Lesotho, Bhutan, Nepal, Guinea-Bissau and Malawi.

Countries that were not on the list of priorities for trade expansion were divided on the basis of economic performance and economic structure. In the first instance, countries with strong dependence on remittances and official development assistance (more than $20 \%$ of GDP) were identified. This indicator has been identified as a priority because it has a significant impact on the country's economy, economic activity and the evolution of the economic structure. Countries dependent on external sources of finance tend to have lower domestic production and consumption, strong climate factors and a high probability of natural disasters, 
and special development strategies less related to the expansion of local production and exports. Most of them either have very small populations (Kiribati, Sao Tome and Principe, Tuvalu), are at war (Somalia, Central African Republic, Afghanistan) or are highly dependent on natural factors (Haiti).

The remaining countries were further divided into clusters according to the role of the main sectors in the economy (agriculture, manufacturing, services), as proposed by the UN Development Policy Committee [Bellman, Tipping, 2015]. The criterion for separation was the increase in the share of a specific sector in GDP over the last 10 years (from 2007 to 2017). When the share of two sectors increased simultaneously during the period under review, the high-value-added sector was selected as the main sector. An exception is that Burundi, despite the growth of the service sector, has been classified as a cluster of agricultural countries because of the very high importance of agriculture in the economy (more than $90 \%$ of the population is employed in this sector).

A cluster of countries dependent on extractive industries was also added. Since most least developed countries did not have data on the value added of the mining sector, natural rents as calculated by the World Bank were chosen as the criterion. Countries with natural rents of more than $20 \%$ of GDP were included in this cluster. In addition, Yemen (the decline in the role of mining due to the military conflict) and Eritrea (the lack of data on the structure of industries since 2011, the share of natural rents in GDP of about 20\%). were added.

\section{Possible Ways for BRICS to Support LDC Exports}

Based on the proposed clustering, potential directions for expanding exports from LDCs can be identified. Given the active involvement of BRICS in the global governance system, supporting sustainable development and positioning itself as a centre of expertise for developing economies, it could take a more active role in addressing the problem of achieving the SDGs, especially in the current environment of strong volatility and uncertainty in the dynamics of international trade. Currently, the official documents of BRICS countries are limited to declaring support for sustainable development and developing countries, without their own ambitious agenda in this area.

The BRICS agenda could include both increasing exports from the LDCs identified in the previous section and providing advisory and financial support to other LDCs.

With regard to LDCs that are promising in terms of increasing exports to BRICS countries, the following can be noted. The existing trade regime between the LDCs and BRICS is characterized by the provision of trade preferences by BRICS countries for most of the goods supplied from the least developed countries in the form of a reduction to zero customs duty rates. In such a way, China applies a duty-free tariff to $97 \%$ of LDC commodity items, India to 96.4\%, Brazil to $80 \%$ and Russia (within the EAEU) to $61.4 \%$ [UN, 2018, WTO, 2019]. ${ }^{7}$ According to rough estimates by the Organisation for Economic Co-operation and Development (OECD), measures used by countries to facilitate trade procedures can generally reduce trade costs for low-income countries by $14.5 \%$ [Vorontsova, 2018]. Empirical calculations carried out by UN experts in 2016 also confirm the importance of using such measures in trade for LDCs [Klassen et al., 2016]. Given that BRICS countries, especially China and India, are the leaders in tariff preferences for LDCs among developing countries, existing measures are already making a significant contribution to supporting exports from LDCs. This is confirmed by the excess of Chinese imports from LDCs over imports from the European Union [Lisitsa, 2017]. At the

\footnotetext{
${ }^{7}$ With regard to South Africa, there is no information on the granting of tariff preferences for LDCs on the official websites of international organizations.
} 
same time, this study suggests measures that would address many of the complexities associated with preferential treatment in trade for LDCs. The remaining unresolved issues lead to the fact that LDCs do not fully use the preferences provided, including by BRICS countries [Lard, 2015\$ WTO, 2020].

The uniform regulations applied by BRICS countries, their transparency and their openness play a significant role in reducing costs when exporting products. Thus, the creation of common lists of LDCs entitled to use tariff preferences on the BRICS platform would be promising, along with the specification of economic parameters for classifying countries as least developed. Due to the fact that the rules of origin of goods that are applied to products from LDCs differ significantly, it is important to form a single information window with the requirements (obtaining a certificate, going through administrative procedures, and so on) to obtain preferences for exporters from LDCs. A breakthrough could be the discussion of the issue of the cumulative calculation of the contribution of all LDCs to the products exported from one of them, that is, determining the cases when goods can be considered, for the purpose of obtaining tariff preferences from the BRICS countries, to have been "produced in the LDCs" [Lisitsa, 2017]. It is also significant that a single BRICS bloc speak on this issue at international platforms, in particular in the World Trade Organization (WTO), and support, as far as possible, the initiatives of colleagues to unite in this area.

With regard to LDCs that are unviable in terms of increasing exports but are highly dependent on migrant remittances and official development assistance, the following can be noted. Due to the weak predictability of aid flows to development and the possibility of their reduction in a crisis situation, as happened in previous crises [Balter, Morozkina, 2018], a large share of this source of financing in GDP itself becomes a source of instability, especially in the current context. Despite the announcement by key donor countries of "striving to protect OECD budgets" [OECD, 2020] on 6 April 2020, certainly not all donor countries can fulfil their obligation. Therefore, in order to protect LDCs in the future, BRICS may propose the creation of special general funds to support LDCs, in particular, allocating funds for the development of export industries, which will not depend on the individual budgets of donor states.

The greatest support for exports is required by countries that are viable in terms of increasing exports but have a high share of the agricultural and mining sectors. In the first case, this is due to climate conditions and dependence on weather, as well as the volatility of prices for agricultural products. The experience of BRICS countries in the development of precision farming and digitalization of agriculture can be used to increase and improve the export stability of such countries. Some LDCs are already undertaking measures in these areas; in particular, Uganda has created an application to conduct auctions for farmers to sell their products, the Technical Centre for Agricultural and Rural Cooperation is creating a farmer database, and Tanzania has developed an application of best practices for growing certain agricultural crops [Krishnan, 2018]. Among BRICS countries, Brazil has achieved the greatest success in these areas [Borghi et al., 2016]; however, the others are actively implementing national strategies in this area.

Least developed countries with a high share of the extractive sector tend to have high unemployment and low levels of human capital, which hinders economic diversification and further development, including of exports. In such cases, they can use the experience of BRICS countries, in particular Russia, in applying budgetary rules and creating a fund that accumulates amounts received from the export of natural resources during a period of high prices. The use of this fund for stabilization during a crisis or for the implementation of long-term development projects (infrastructure, health care, education) could potentially support the diversification of the country's economy and increase non-resource exports. 


\begin{tabular}{|c|c|c|c|c|c|c|c|c|c|c|c|c|c|c|c|c|}
\hline 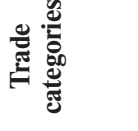 & $\because$ & & - & - & - & $\sim$ & $\sim$ & $\sim$ & $\sim$ & $\sim \mid c$ & $\sim m$ & m & $m$ & $m$ & $m$ & $m$ \\
\hline 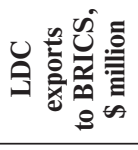 & $\Xi$ & बे & $\begin{array}{l}\tilde{\lambda} \\
\hat{\lambda} \\
\end{array}$ & $\begin{array}{l}\stackrel{\overbrace{}}{6} \\
+\end{array}$ & $\begin{array}{l}\tilde{O} \\
\stackrel{0}{ } \\
\sim\end{array}$ & $\stackrel{\bar{n}}{m}$ & $\begin{array}{l}\stackrel{n}{a} \\
\dot{c} \\
m\end{array}$ & ફે & 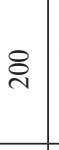 & $\begin{array}{l}\infty \\
\stackrel{\infty}{\sim} \\
-\end{array}$ & \begin{tabular}{l|l}
$\stackrel{D}{\infty}$ & f \\
- &
\end{tabular} & $\hat{\varrho}$ & $\stackrel{n}{m}$ & $\Xi$ & बे & 文 \\
\hline 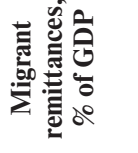 & 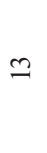 & $\stackrel{\infty}{\stackrel{\sim}{\sim}}$ & $\because$ & ले & $\stackrel{\circ}{i}$ & in & $\stackrel{m}{0}$ & $\stackrel{\text { I }}{\rightarrow}$ & : & $\hat{\circ}$ & 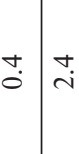 & $\mid \begin{array}{l}\infty \\
\infty \\
\infty\end{array}$ & $\stackrel{\sim}{\vec{\lambda}}$ & $\stackrel{b}{i}$ & $\begin{array}{l}0 \\
\infty \\
\infty \\
\sim\end{array}$ & $\stackrel{+}{\leftrightarrows}$ \\
\hline घิ & $\simeq$ & 궁 & $\begin{array}{l}\infty \\
\dot{b} \\
\dot{\sigma}\end{array}$ & $\stackrel{\infty}{\infty}$ & 享 & ñ & $\stackrel{\vec{m}}{\vec{m}}$ & ஓें & 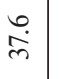 & $\stackrel{\vec{m}}{\text { ले }}$ & 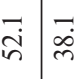 & $\underset{n}{n}$ & ñ & $\mid \begin{array}{l}\text { ì } \\
\text { in }\end{array}$ & $\stackrel{0}{\dot{m}}$ & $\stackrel{\circ}{\circ}$ \\
\hline $\begin{array}{ll}50 \\
\text { के do }\end{array}$ & $=$ & ڤิ) & $\begin{array}{l}\dot{0} \\
\dot{m} \\
\dot{m}\end{array}$ & $\underset{\dot{\gamma}}{\ddot{\gamma}}$ & $\begin{array}{l}0 \\
\dot{+} \\
\dot{f}\end{array}$ & ते & $\begin{array}{l}\dot{0} \\
\dot{q}\end{array}$ & $\stackrel{n}{m}$ & : & 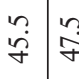 & 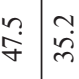 & $\stackrel{\vec{f}}{\vec{\forall}}$ & $\ddot{n}$ & $\mid \begin{array}{l}n \\
\dot{f} \\
\dot{f}\end{array}$ & $\mid \begin{array}{c}\infty \\
\dot{\sigma} \\
\dot{q}\end{array}$ & $\stackrel{\circ}{\circ}$ \\
\hline 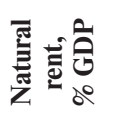 & 으 & $\stackrel{\infty}{\stackrel{\sim}{\sim}}$ & $\ddot{\ddot{\omega}}$ & $\vec{i}$ & $\stackrel{n}{2}$ & $\hat{\sigma}$ & ֻี่ & $\vec{d}$ & $\stackrel{+}{\doteq}$ & : & ì & $\stackrel{n}{\varrho}$ & in & $\stackrel{0}{0}$ & $\exists$ & $\begin{array}{l}\text { ì } \\
\text { ते }\end{array}$ \\
\hline 㟟 & $a$ & $\overrightarrow{\text { ㄱ. }}$ & $\underset{f}{\stackrel{f}{\sim}}$ & $\stackrel{\tilde{I}}{\tilde{I}}$ & $\stackrel{\stackrel{+}{i}}{+}$ & $\stackrel{\infty}{\stackrel{\sim}{\sim}}$ & $\stackrel{\vec{m}}{m}$ & $\overrightarrow{\mathrm{i}}$ & $\underset{\infty}{-}$ & $\begin{array}{ll}\vec{n} & m \\
m\end{array}$ & \begin{tabular}{c|c}
$m$ & $\infty$ \\
$m$ & $\stackrel{p}{\sigma}$
\end{tabular} & 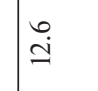 & ळे & $\stackrel{+}{ \pm}$ & $\stackrel{\sim}{\ddot{n}}$ & $\stackrel{0}{\circ}$ \\
\hline 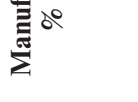 & $\infty$ & ڤे & $\frac{9}{6}$ & 当 & $\stackrel{\infty}{\infty}$ & $\stackrel{n}{\stackrel{n}{d}}$ & $\begin{array}{l}\infty \\
\dot{m} \\
\dot{m}\end{array}$ & $\vec{m}$ & $\begin{array}{l}\infty \\
\ddot{\sim} \\
\dot{\sim}\end{array}$ & $\underset{\overbrace{}}{\tilde{\lambda}}$ & $\stackrel{g}{\vec{m}} \overrightarrow{\dot{g}}$ & $\stackrel{\sim}{m}$ & กั & $\vec{\infty}$ & $\ddot{2}$ & $\stackrel{0}{\circ}$ \\
\hline 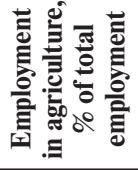 & $n$ & $\stackrel{\infty}{\stackrel{\sim}{\grave{d}}}$ & $\begin{array}{l}0 \\
\dot{8} \\
i n\end{array}$ & $\hat{\dot{b}}$ & $\begin{array}{l}0 \\
\stackrel{+}{i}\end{array}$ & $\grave{I}$ & تُ & $\stackrel{m}{n}$ & वे & ఫें & $\ddot{s}$ & $\stackrel{m}{0}$ & $\vec{a}$ & 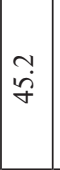 & $\stackrel{0}{i}$ & \\
\hline 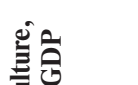 & 6 & $\overrightarrow{\stackrel{े}{े}}$ & $\stackrel{0}{0}$ & $\hat{a}$ & $\begin{array}{l}0 \\
\ddot{i}\end{array}$ & 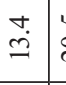 & "ֶ. & 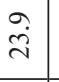 & $\begin{array}{l}m \\
\infty \\
m \\
m\end{array}$ & 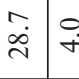 & \begin{tabular}{l|l}
$\circ$ & $\stackrel{0}{+}$ \\
\end{tabular} & 当 & $\overline{6}$ & $\vec{D}$ & $\vec{\sim}$ & $\stackrel{\circ}{\circ}$ \\
\hline 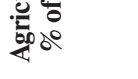 & in & ڤิ) & in & $\stackrel{\vec{\lambda}}{\vec{i}}$ & $\begin{array}{l}\infty \\
\ddot{\imath} \\
\tilde{i}\end{array}$ & $\stackrel{\infty}{\stackrel{\Xi}{=}}$ & $\begin{array}{l}\infty \\
\dot{\varphi} \\
\dot{\varphi}\end{array}$ & $\stackrel{\bullet}{\ddot{\imath}}$ & $\stackrel{\nabla}{\dot{m}}$ & \begin{tabular}{c|c}
$\stackrel{\sim}{\sim}$ & $\bar{\Xi}$
\end{tabular} & $\overrightarrow{\mathrm{I}} \quad \hat{\operatorname{b}}$ & $\mid \begin{array}{l}\tilde{\gamma} \\
\tilde{F}\end{array}$ & $\ddot{n}$ & 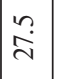 & $\frac{\stackrel{c}{m}}{m}$ & $\stackrel{\circ}{\circ}$ \\
\hline 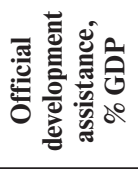 & $\nabla$ & $\stackrel{\infty}{\stackrel{\sim}{\sim}}$ & $\stackrel{n}{0}$ & $\ddot{r}$ & $\stackrel{\sim}{I}$ & $\vec{m}$ & ఫे & సֶ. & $\stackrel{\infty}{\varrho}$ & $\dot{\vec{m}}$ & $\vec{m} \quad \bar{\sigma}$ & {$\left[\begin{array}{l}\stackrel{N}{\infty} \\
\mathscr{\infty}\end{array}\right.$} & $\hat{b}$ & $\hat{\varrho}$ & : & $\ddot{\underline{n}}$ \\
\hline نे & $n$ & & $\begin{array}{l}\frac{\pi}{8} \\
0 \\
\frac{8}{<}\end{array}$ & 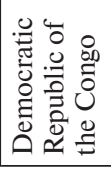 & 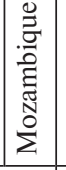 & 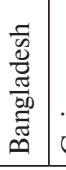 & : & 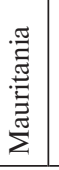 & $\overline{\bar{\pi}}$ & 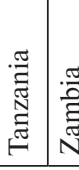 & 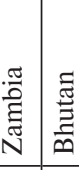 & 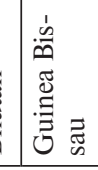 & 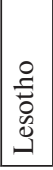 & 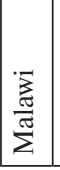 & \begin{tabular}{|}
$\overline{\tilde{a}}$ \\
$\overline{\tilde{z}}$ \\
\end{tabular} & 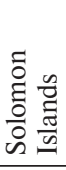 \\
\hline & $\sim$ & & \multicolumn{2}{|c|}{ 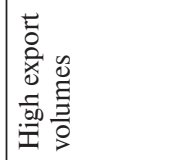 } & & \multicolumn{5}{|c|}{ 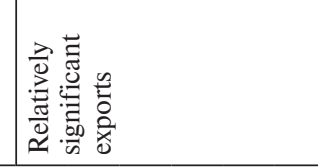 } & & \multicolumn{5}{|l|}{ 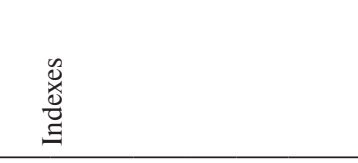 } \\
\hline & - & & \multicolumn{14}{|c|}{ әૂ!̣рәdsıә } \\
\hline
\end{tabular}




\begin{tabular}{|c|c|c|c|c|c|c|c|c|c|c|c|c|c|c|c|c|c|}
\hline 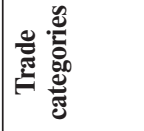 & $\because$ & 0 & 0 & 0 & 0 & 0 & 0 & 0 & 0 & 0 & 0 & 0 & 0 & 0 & 0 & 0 & 0 \\
\hline 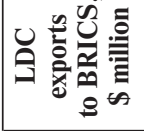 & \pm & 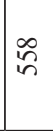 & $\hat{n}$ & $\stackrel{\mathbb{N}}{\sim}$ & $N$ & $\stackrel{\infty}{\sim}$ & 0 & $\stackrel{F}{\Im}$ & 0 & $=$ & $\hat{\sim}$ & rq & fै & $\overrightarrow{\widetilde{N}}$ & F & 2 & $\because$ \\
\hline 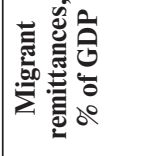 & $\cong$ & F & $\stackrel{0}{\circ}$ & in & $n$ & $\stackrel{\sim}{m}$ & $\stackrel{\sim}{f}$ & $\stackrel{\circ}{0}$ & $\because$ & $\stackrel{0}{-}$ & $\begin{array}{l}\infty \\
\varrho \\
\varrho\end{array}$ & $\bar{i}$ & $\overrightarrow{0}$ & $\stackrel{n}{\rightarrow}$ & ๙ุ. & $\stackrel{n}{*}$ & ळे \\
\hline \multirow{2}{*}{ 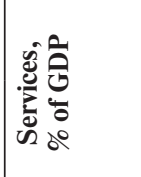 } & $\simeq$ & in & $\frac{\partial}{\vec{\gamma}}$ & $\stackrel{+}{ \pm}$ & $\stackrel{\nabla}{\ddot{b}}$ & $\begin{array}{l}m \\
\infty \\
\infty \\
m\end{array}$ & $\grave{g}$ & $\ddot{0}$ & $\ddot{0}$ & $\frac{m}{\dot{q}}$ & 管 & 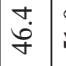 & $\frac{0}{i n}$ & $\stackrel{\vec{\sim}}{\stackrel{m}{m}}$ & $\begin{array}{l}\infty \\
\stackrel{\sim}{\sim}\end{array}$ & $\vec{F}$ & $\stackrel{\circ}{\circ}$ \\
\hline & $=$ & ma & $\because$ & $\stackrel{\stackrel{\circ}{\dot{\gamma}}}{ }$ & 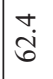 & $\begin{array}{l}n \\
2 \\
\tilde{m}\end{array}$ & 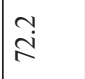 & $\stackrel{\circ}{\circ}$ & $\because$ & ले & 辛 & 我 & $\ddot{n}$ & 㝎 & $\stackrel{\dot{m}}{\dot{m}}$ & के & $\because$ \\
\hline 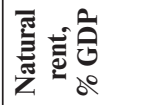 & 으 & $\hat{\sigma}$ & $\stackrel{0}{\ddot{2}}$ & 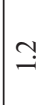 & $\overrightarrow{0}$ & $\stackrel{m}{\varrho}$ & $\hat{i}$ & $\stackrel{\sim}{\check{n}}$ & $\because$ & 苞 & $\stackrel{\vec{c}}{\mathrm{i}}$ & ڤे & $\stackrel{\infty}{\sim}$ & ĩ & 苞 & $\stackrel{\partial}{\ddot{\eta}}$ & $\stackrel{\infty}{0}$ \\
\hline \multirow{2}{*}{ 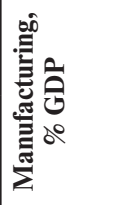 } & $a$ & $\overrightarrow{\mathrm{i}}$ & $\hat{\stackrel{\sim}{~}}$ & $\frac{3}{0}$ & $\stackrel{\searrow}{\leftrightharpoons}$ & $\stackrel{a}{\underline{n}}$ & $\ddot{n}$ & $\because$ & $\stackrel{m}{\sim}$ & $\stackrel{\circ}{=}$ & $\vec{a}$ & $\begin{array}{l}\infty \\
\ddot{n} \\
\end{array}$ & $\ddot{\ddot{i}}$ & is & $\begin{array}{l}m \\
n \\
n\end{array}$ & ?̊. & $\exists$ \\
\hline & $\infty$ & ठें & $\stackrel{\circ}{\circ}$ & 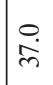 & $\stackrel{n}{\varrho}$ & $\stackrel{\sim}{\simeq}$ & $\begin{array}{l}\infty \\
\subseteq \\
\simeq\end{array}$ & $\stackrel{\circ}{\circ}$ & $\stackrel{\infty}{\sim}$ & $\stackrel{1}{=}$ & $\stackrel{\stackrel{\sim}{\Xi}}{\beth}$ & $\stackrel{\dddot{n}}{\check{n}}$ & $\overrightarrow{\grave{\lambda}}$ & $\hat{a}$ & $\begin{array}{l}\ddot{\bullet} \\
\ddot{n}\end{array}$ & $\ddot{2}$ & $\stackrel{\infty}{\sim}$ \\
\hline 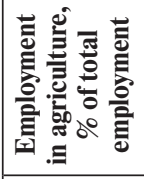 & - & $\begin{array}{l}\infty \\
\dot{q} \\
\dot{q}\end{array}$ & $\underset{\infty}{\infty}$ & ते & 퐆 & in & "n & $\stackrel{m}{\infty}$ & 兵 & ì & $\stackrel{\vec{n}}{\vec{n}}$ & $\begin{array}{l}0 \\
\dot{6}\end{array}$ & $\stackrel{\vec{i}}{\check{m}}$ & 离 & $\begin{array}{l}0 \\
\text { ले }\end{array}$ & $\begin{array}{l}\infty \\
i \\
i\end{array}$ & $\stackrel{+}{i}$ \\
\hline \multirow{2}{*}{ 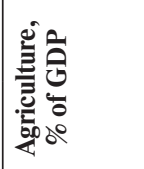 } & 0 & 吕 & $\begin{array}{l}\infty \\
\text { in } \\
\text { ran }\end{array}$ & $\stackrel{9}{\triangleq}$ & 文 & $\hat{\text { ले }}$ & $\vec{a}$ & $\because$ & 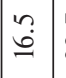 & $\overrightarrow{\dot{m}}$ & $\frac{g}{\dot{m}}$ & 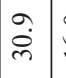 & 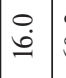 & $\begin{array}{l}3 \\
\tilde{B}\end{array}$ & $\mid \begin{array}{l}\infty \\
\dot{b} \\
i n\end{array}$ & $\begin{array}{l}\stackrel{\bullet}{+} \\
\stackrel{\sim}{\sim}\end{array}$ & $\begin{array}{l}\infty \\
\text { ¿ें }\end{array}$ \\
\hline & in & : & $\stackrel{\circ}{\circ}$ & $\widehat{\grave{i}}$ & $\ddot{\sim}$ & $\stackrel{\circ}{\stackrel{\vec{\gamma}}{ }}$ & $\stackrel{\infty}{\infty}$ & $\stackrel{\circ}{\circ}$ & $\begin{array}{l}\sim \\
\ddot{\sim} \\
\end{array}$ & $\overrightarrow{\breve{y}}$ & $\begin{array}{l}\ddot{N} \\
\ddot{\mathrm{N}}\end{array}$ & $\stackrel{\circ}{\ddot{m}}$ & $\stackrel{\stackrel{i}{i}}{\mathrm{I}}$ & ì & 吕 & 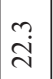 & 完 \\
\hline 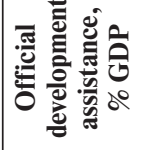 & t & $\stackrel{n}{\stackrel{n}{d}}$ & 㐫 & $\stackrel{\check{I}}{\beth}$ & $\stackrel{\check{f}}{\vec{f}}$ & $\stackrel{\circ}{\vec{\lambda}}$ & 米 & $\overrightarrow{\dot{i}}$ & 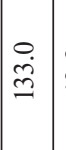 & ભे & $\overrightarrow{0}$ & $\stackrel{\infty}{=}$ & $\stackrel{\infty}{\sim}$ & $\stackrel{0}{\circ}$ & n? & $\overrightarrow{\mathrm{I}}$ & $\stackrel{m}{m}$ \\
\hline \multirow[t]{3}{*}{ 己 } & $m$ & 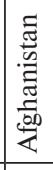 & 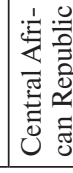 & $\begin{array}{l}: \text { : } \\
\text { 壱 }\end{array}$ & 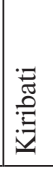 & \begin{tabular}{|l} 
\\
\\
.00 \\
$Z$ \\
\end{tabular} & 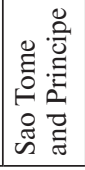 & 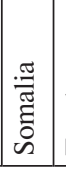 & 离 & 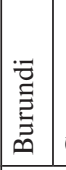 & $\mid \begin{array}{l}0 \\
0 \\
0 \\
0 \\
\tilde{0} \\
0 \\
0\end{array}$ & 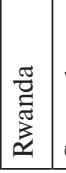 & 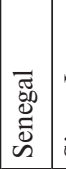 & 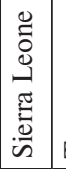 & $\begin{array}{l}0 \\
\stackrel{0}{\infty} \\
\stackrel{0}{\ominus} \\
\ominus\end{array}$ & 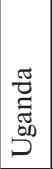 & 䓌 \\
\hline & $\sim$ & \multicolumn{7}{|c|}{ 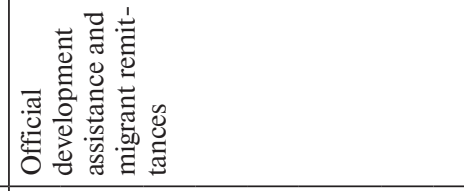 } & & \multicolumn{8}{|l|}{ 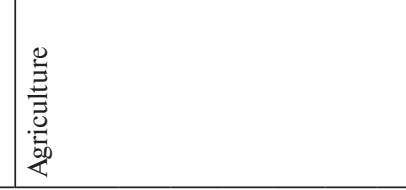 } \\
\hline & - & \multicolumn{16}{|c|}{ әм!̣๖әds.ıəd-uoN } \\
\hline
\end{tabular}




\begin{tabular}{|c|c|c|c|c|c|c|c|c|c|c|c|c|c|c|c|c|}
\hline 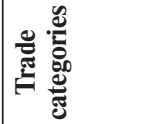 & $\because$ & 0 & 0 & 0 & 0 & 0 & 0 & 0 & 0 & 0 & 0 & 0 & 0 & 0 & 0 & 0 \\
\hline 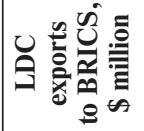 & \pm & \&̊ & $\widehat{\widehat{\sigma}}$ & $\stackrel{ }{\sim}$ & $\cong$ & 会 & 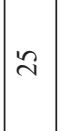 & $\begin{array}{l}\infty \\
\infty \\
\infty\end{array}$ & $\mid \begin{array}{c} \pm \\
\infty \\
-0\end{array}$ & $\vec{F}$ & $\stackrel{ \pm}{=}$ & 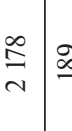 & $\stackrel{f}{\infty}$ & \begin{tabular}{l|l}
$y^{y}$ & $\vec{m}$
\end{tabular} & $\stackrel{\partial}{\partial}$ & $\stackrel{\overline{\mathrm{N}}}{\mathrm{J}}$ \\
\hline 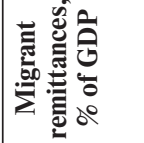 & $\cong$ & $\stackrel{\sim}{m}$ & $\stackrel{0}{0}$ & $\because$ & $\overrightarrow{ \pm}$ & $\ddot{\circ}$ & $\ddot{m}$ & $\stackrel{+}{\mathrm{I}}$ & \begin{tabular}{|l|}
$\infty$ \\
in
\end{tabular} & $\begin{array}{l}n \\
0\end{array}$ & $\stackrel{n}{\mathfrak{I}}$ & $\stackrel{9}{\rightarrow}$ & $\stackrel{9}{\rightarrow} \stackrel{\circ}{i}$ & $\vec{i} \mid \vec{m}$ & $\stackrel{\circ}{+}$ & $\stackrel{\circ}{-}$ \\
\hline \multirow{2}{*}{ 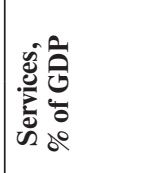 } & $\simeq$ & $\vec{g}$ & $\begin{array}{l}n \\
m \\
m\end{array}$ & $\because$ & 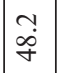 & $\begin{array}{l}0 \\
\text { i } \\
\text { in }\end{array}$ & $\underset{\forall}{\nexists \dot{f}}$ & $\vec{a}$ & $\hat{\dot{m}}$ & \begin{tabular}{|l|}
0 \\
迥
\end{tabular} & $\stackrel{\nabla}{\stackrel{2}{n}}$ & $\stackrel{n}{q}$ & 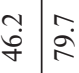 & $\stackrel{i}{i}$ & 守 & $\mid \begin{array}{l}\infty \\
\dot{\sigma} \\
\dot{\sigma}\end{array}$ \\
\hline & $=$ & $\begin{array}{l}\infty \\
i \\
i\end{array}$ & $\stackrel{\sim}{m}$ & $\because$ & \begin{tabular}{|l|}
$n$ \\
$\infty$ \\
$\infty$ \\
$i$
\end{tabular} & $\because$ & $\stackrel{\varrho}{\mathfrak{I}}$ & $\frac{n}{m}$ & $\mid \begin{array}{l}n \\
\infty \\
\infty \\
m\end{array}$ & $\overrightarrow{\text { m}}$ & ì. & 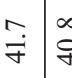 & \begin{tabular}{l|l}
$\infty$ & $\circ$ \\
$\dot{q}$ & $\stackrel{0}{0}$
\end{tabular} & \begin{tabular}{l|l}
$\dot{b}$ \\
$\dot{b}$
\end{tabular} & $\because$ & ?े \\
\hline 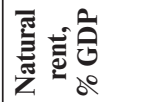 & 으 & iे & ¿̇ & $\vec{a}$ & 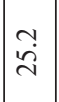 & $\stackrel{\vec{J}}{\dot{g}}$ & $\frac{n}{m}$ & 9 & $\cong$ & $\ddot{0}$ & $\begin{array}{l}\infty \\
i n\end{array}$ & $\stackrel{1}{\varrho}$ & \begin{tabular}{l|l}
$\infty$ & \multirow{0}{*}{.}
\end{tabular} & 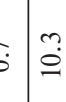 & $\vec{r}$ & $\underset{+}{\stackrel{0}{+}}$ \\
\hline \multirow{2}{*}{ 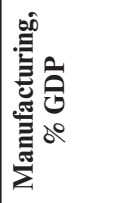 } & $a$ & $\hat{\stackrel{i}{~}}$ & $\begin{array}{l}0 \\
\dot{I}\end{array}$ & $\because$ & 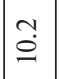 & $\vec{m}$ & \begin{tabular}{l|}
$\infty$ \\
$\dot{g}$ \\
$\dot{q}$
\end{tabular} & $\overrightarrow{\vec{g}}$ & \begin{tabular}{|l|}
$\infty$ \\
$\dot{m}$ \\
$\dot{m}$
\end{tabular} & 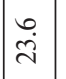 & $\stackrel{\partial}{\triangleq}$ & \begin{tabular}{l|l}
$\hat{m}$ & $n$
\end{tabular} & $\stackrel{n}{\stackrel{n}{\sim}} \stackrel{\infty}{=}$ & 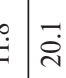 & ?్ల. & $\stackrel{n}{i}$ \\
\hline & $\infty$ & $\stackrel{\text {. }}{=}$ & $\hat{a}$ & $\stackrel{2}{2}$ & $\stackrel{2}{2}$ & $\begin{array}{l}0 \\
\dot{0} \\
\dot{m}\end{array}$ & $\mid \begin{array}{l}\infty \\
\infty \\
\infty\end{array}$ & $\begin{array}{l}n \\
\dot{q} \\
\mathfrak{g}\end{array}$ & 卞 & $\stackrel{\circ}{=}$ & $\stackrel{9}{=}$ & \begin{tabular}{lll}
$\dot{d}$ & \multirow{2}{c}{} &
\end{tabular} & \begin{tabular}{l|l}
$\stackrel{\sim}{\sim}$ & $\stackrel{0}{0}$
\end{tabular} & $\begin{array}{l}\dot{0} \\
\dot{0}\end{array}$ & $\stackrel{\nabla}{\stackrel{\sim}{~}}$ & 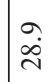 \\
\hline 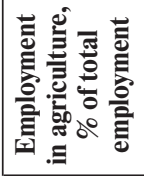 & - & $\begin{array}{l}0 \\
\infty \\
\text { i }\end{array}$ & 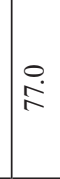 & 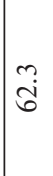 & \begin{tabular}{l|}
$\stackrel{y}{*}$ \\
$\dot{f}$
\end{tabular} & 䇊 & $\begin{array}{l}\stackrel{P}{\dot{F}} \\
\vec{F}\end{array}$ & 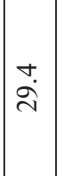 & $\begin{array}{l}n \\
\tilde{m} \\
\tilde{m}\end{array}$ & $\mid \begin{array}{l}1 \\
\infty \\
\infty \\
0\end{array}$ & $\vec{a}$ & $\begin{array}{l}0 \\
\dot{b}\end{array}$ & \begin{tabular}{l|l}
$\infty$ & $n$ \\
$\dot{q}$ & $n$ \\
\end{tabular} & $\begin{array}{l}\dot{n} \\
\dot{6} \\
\dot{b}\end{array}$ & $\stackrel{m}{i n}$ & qे \\
\hline \multirow{2}{*}{ 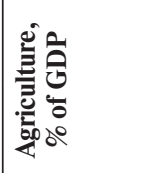 } & 6 & 吕 & $\begin{array}{l}0 \\
\infty \\
\infty\end{array}$ & $\because$ & $\vec{m}$ & $\stackrel{+}{\stackrel{0}{0}}$ & $\stackrel{+}{\stackrel{0}{0}}$ & $\dot{0}$ & $\begin{array}{l}\dot{\sim} \\
\vec{\sim}\end{array}$ & $\begin{array}{l}\infty \\
\infty \\
m\end{array}$ & $\stackrel{\circ}{\vec{\sim}}$ & 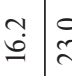 & 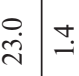 & $\begin{array}{l}+ \\
\dot{\sim}\end{array}$ & $\stackrel{m}{\tilde{v}}$ & in \\
\hline & in & ते & 官 & $\stackrel{m}{\stackrel{\sim}{\sim}}$ & $\begin{array}{l}0 \\
\dot{0} \\
6\end{array}$ & $\because$ & $\mid \begin{array}{l}0 \\
i \\
i n\end{array}$ & $\hat{\sigma}$ & $\hat{\vec{\lambda}}$ & 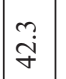 & $\begin{array}{l}0 \\
\ddot{\sim}\end{array}$ & $\begin{array}{l}\infty \\
\\
\end{array}$ & 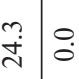 & 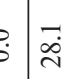 & $\mid \begin{array}{c}m \\
\dot{q}\end{array}$ & ஸั \\
\hline 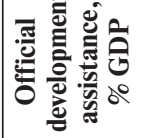 & $\nabla$ & $\overrightarrow{\mathrm{I}}$ & $a$ & $\stackrel{\sim}{m}$ & 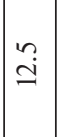 & $\hat{a}$ & $\stackrel{?}{\sim}$ & 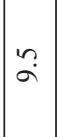 & $\stackrel{+}{\sim}$ & ? & ठे. & \begin{tabular}{c|c}
$\stackrel{\infty}{r}$ & $\sigma$
\end{tabular} & 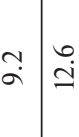 & 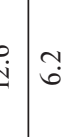 & $\stackrel{\vartheta}{\dot{\gamma}}$ & 9 \\
\hline \multirow[t]{3}{*}{ 昱 } & $m$ & 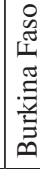 & चु & 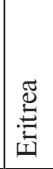 & 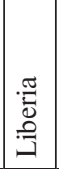 & 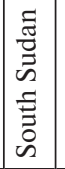 & 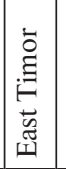 & 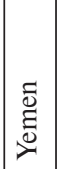 & 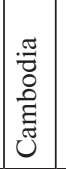 & 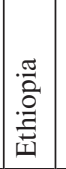 & 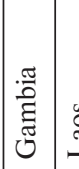 & 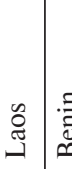 & 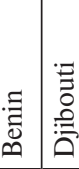 & 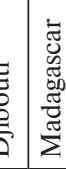 & 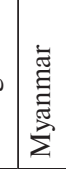 & 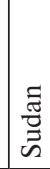 \\
\hline & $\sim$ & \multicolumn{7}{|c|}{ 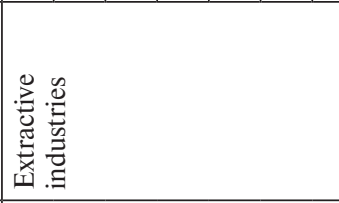 } & \multicolumn{4}{|l|}{ 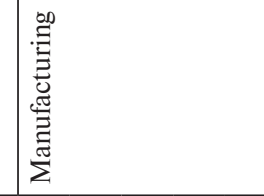 } & \\
\hline & - & \multicolumn{15}{|c|}{ 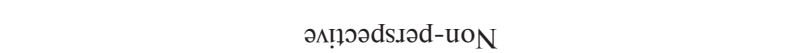 } \\
\hline
\end{tabular}

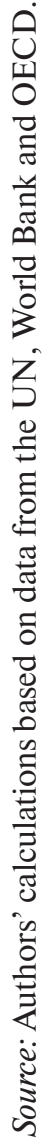




\section{Conclusion}

In this article, the main LDC export tendencies to BRICS were analyzed. The prospects for achieving SDG 17 in terms of trade with the least developed countries were assessed and clustering of the least developed countries in terms of priority measures for support from BRICS countries was proposed.

In contrast to a previously proposed clustering of LDCs [Cornia, Scognamillo, 2016], dividing countries only on the basis of national characteristics (population, dominant economic sector, state of war), this study made it possible to identify those least developed countries that are able to directly increase trade volumes (13 out of 47 ) with BRICS. It should be noted that most LDCs are located in Africa and the greatest prospects are associated with the increase of exports to South Africa and India. Brazil and Russia, with the direct approach, are barely involved in the implementation of this goal. To form an active and ambitious BRICS agenda for the implementation SDG 17, LDCs were clustered on the basis of the prospects for direct trade development and the structure of the LDCs' economy. It was emphasized that, due to differences in LDC economies, a uniform approach to the issue cannot be applied.

The potential areas in which BRICS could support LDC exports highlighted by this analysis can serve as a starting point for building trade and economic relations between countries, as well as enhancing BRICS' contribution to the expansion of international trade and the development agenda. The creation of a unified list of LDCs entitled to benefit from tariff preferences, as well as the formation of a single information window with the requirements for obtaining preferences, will not only specify the requirements for suppliers from LDCs and significantly facilitate their access to the BRICS market, but will also have a positive effect on the image of BRICS countries. A similar effect is also expected from the creation of special general funds to support LDCs, in particular, by allocating funds for the development of export industries that do not depend on the donors' individual budgets. Opportunities for LDCs to use the experience of BRICS countries in terms of expanding the use of precision farming and digitalization of agriculture, as well as the application of the budgetary rule and the creation of a reserve fund, could have a positive effect on investment flows from BRICS to LDCs, the creation of joint ventures, and the export of science-intensive and other services from BRICS. A joint BRICS statement on the achievement of SDG 17.11 on international platforms, in particular at the WTO, and support of partners' initiatives could lead to strengthening of foreign economic relations and the formation of political coalitions in other areas.

To sum up, BRICS can support export development not only of those countries with which it cooperates directly in the field of trade, but also realize its potential as a centre of expertise and support for developing countries by promoting the growth of exports from LDCs that are not yet of interest to BRICS in terms of increasing imports. The directions outlined in this article may have positive consequences not only for the economies of the least developed countries, but also the BRICS economies. Such consequences can be clarified with further investigation of this issue.

\section{References}

Azevêdo R. (2020). Remarks: Trade Forecast Press Conference, 8 April. World Trade Organization. Available at: https://www.wto.org/english/news_e/spra_e/spra303_e.htm (accessed 10 December 2020).

Balter E., Morozkina A. (2018). Raspredelenie dvustoronnej pomoshchi mezhdunarodnomu razvitiyu: izmeneniya posle finansovogo krizisa [Bilateral Aid Allocation for International Development: Impact of the Financial Crisis]. Vestnik moskovskogo universiteta. Seriya 6. Ekonomika, no 4, pp. 100-22 (in Russian). 
Basile E., Cecchi C. (2019). The Uncertain Sustainability of BRICS Strategies for Sustainable Development. BRICS National Research Committee, 7 June. Available at: http://www.nkibrics.ru/posts/ show/5cfa4f8e6272692ee0100000 (accessed 10 December 2020).

Bellman C., Tipping A. (2015). The Role of Trade and Trade Policy in Advancing the 2030 Development Agenda. International Development Policy, vol. 6, no 2. Available at: https://doi.org/10.4000/poldev.2149.

Bobylev S.N., Solov'eva S.V. (2016). OON: smena celej [United Nations: Redefining Goals]. World Economy and International Relation, vol. 60 no. 5, pp. 30-9 (in Russian).

Borghi E., Avanzi J., Bortolon L., Luchiari A. Junior, Bortolon E. (2016). Adoption and Use of Precision Agriculture in Brazil: Perception of Growers and Service Dealership. Journal of Agricultural Science, vol. 8, no 11. Available at: http://doi.org/10.5539/jas.v8n11p89.

BRIC (2009). Joint Statement of the BRIC Countries' Leaders. Yekaterinburg, 16 June. Available at: http:// www.brics.utoronto.ca/docs/090616-leaders.html (accessed 10 December 2020).

BRICS (2016). Goa Declaration. Goa, 16 October. Available at: http://www.brics.utoronto.ca/docs/161016goa.html (accessed 10 December 2020).

BRICS-Russia (2020). Priorities of the Russian Federation Presidency in BRICS. Available at: https://bricsrussia2020.ru/russia_in_brics/20191226/1362/Prioritety-predsedatelstva-Rossiyskoy-Federatsii-v-BRIKS. html (accessed 10 December 2020) (in Russian).

Cornia G.A., Scognamillo A. (2016). Clusters of Least Developed Countries, Their Evolution Between 1993 and 2013, and Policies to Expand Their Productive Capacity. CDP Background Paper no 33 (ST/ESA/2016/ CDP/33), United Nations Committee for Development Policy. Available at: https://www.un.org/development/desa/dpad/publication/background-paper-33/ (accessed 10 December 2020).

Donno D., Rudra N. (2019). David and Goliath? Small Developing Countries, Large Emerging Markets, and South-South Preferential Trade Agreements. International Studies Quarterly, vol. 63, no 3, pp. 574-88. Available at: https://doi.org/10.1093/isq/sqz041.

Flento D., Ponte S. (2017). Least-Developed Countries in a World of Global Value Chains: Are WTO Trade Negotiations Helping? World Development, vol. 94, pp. 366-74. Available at: https://doi.org/10.1016/j.worlddev.2017.01.020.

Gay D. (2018). International Support for the Least Developed Countries: A Different Way? United Nations LDC Portal. Available at: https://www.un.org/ldcportal/international-support-for-the-least-developed-countries-a-different-way/ (accessed 10 December 2020).

Government of Brazil (2017). Voluntary National Review on the Sustainable Development Goals. Available at: https://sustainabledevelopment.un.org/content/documents/15806Brazil_English.pdf (accessed 10 December 2020).

Government of China (2017). China's Progress Report on Implementation of the 2030 Agenda for Sustainable Development. Ministry of Foreign Affairs of the People's Republic of China. Available at: http://www.chinadaily.com.cn/specials/China'sProgressReport2(CN).pdf (accessed 10 December 2020).

Government of India (2017). Voluntary National Review Report on the Implementation of the Sustainable Development Goals. Available at: https://sustainabledevelopment.un.org/content/documents/16693India.pdf (accessed 10 December 2020).

Government of Russia (2020). Voluntary National Review of the progress made in the implementation of the 2030 Agenda for Sustainable Development. Available at: https://sustainabledevelopment.un.org/content/ documents/26962VNR_2020_Russia_Report_English.pdf

Government of South Africa (2019). Voluntary National Review: Empowering People and Ensuring Inclusiveness and Equality. Available at: https://sustainabledevelopment.un.org/content/documents/23402RSA_Voluntary_National_Review_Report_The_Final_24_July_2019.pdf (accessed 10 December 2020).

International Trade Centre (ITC) (n. d.). Available at: https://www.trademap.org/ (accessed 7 March 2021).

Khmelevskaya N. (2018). BRICS' Sustainable Development Dialog: Framing Contours to a Common Agenda Through the Intragroup Trade. International Organisations Research Journal, vol. 13, no 4, pp. 74-95. Available at: http://doi.org/10.17323/1996-7845-2018-04-04. 
Klassen S., Martínex-Zarzoso I., Nowak-Lehmann F., Bruckner M. (2016). Trade Preferences for Least Developed Countries. Are they Effective? Preliminary Econometric Evidence. CDP Policy Review No 4, United Nations Committee for Development Policy. Available at: https://www.un.org/development/desa/dpad/wpcontent/uploads/sites/45/publication/CDP-review-2016-4.pdf (accessed 10 December 2020).

Krishnan A. (2018). How AgTech Is Changing East African Economies. Insight Blog, 1 October. Overseas Development Institute. Available at: https://www.odi.org/blogs/10693-how-agtech-changing-east-africaneconomies (accessed 10 December 2020).

Lard S. (2015). Obzor sistem torgovykh preferentsii dlya bedneishikh stran [A Review of Trade Preference Schemes for the World's Poorest Countries]. Trade Policy, no 1/1, pp. 31-77 (in Russian).

Lisitsa K. (2017). Naimenee razvitye strany: problemy razvitiya i integratsii v mirovuyu ekonomiku [Least Developed Countries: Problems of Development and Integration into the World Economy]. Ekonomika. Upravlenie. Innovatsii, vol. 3, no 2, pp. 80-6 (in Russian).

Mikic M., Gilbert J. (2009). Trade Statistics in Policymaking: A Handbook of Commonly Used Trade Indices and Indicators. United Nations Economic and Social Commission for Asia and the Pacific (UN ESCAP). Available at: https://artnet.unescap.org/publications/books-reports/trade-statistics-policymaking-handbook (accessed 7 March 2021).

Morozkina A.K. (2017). BRIKS v sisteme sodejstviya mezhdunarodnomu razvitiyu [BRICS in the International Development Assistance Framework]. Securing Sustainable Development: Financial Initiatives of BRICS Countries: Proceedings of Workshop RISS, 24 October. Moscow: RISS, pp. 148-58 (in Russian).

Navarro-Pabsdorf R.M., Martínez-Alcalá C., Moral-Pajares E. (2020). Can International Trade Help Africa's Least Developed Countries Achieve SDG-1? Sustainability, vol. 12, no 4470. Available at: https://doi. org/10.3390/su12114470.

Nowak W. (2016). China-Africa and India-Africa Trade in the Years 2000-2014. Procedia Economics and Finance, vol. 39, pp. 140-6. Available at: https://doi.org/10.1016/S2212-5671(16)30261-1.

Organisation for Economic Co-Operation and Development (OECD) (2020). Joint Statement by the OECD Development Assistance Committee on the Covid-19 Crisis. 9 April. Available at: https://www.oecd.org/dac/ development-assistance-committee/daccovid19statement.htm (accessed 10 December 2020).

Organisation for Economic Co-Operation and Development (OECD) (n. d.). International Development Statistics. Available at: https://stats.oecd.org/qwids/ (accessed 7 March 2021).

Reinert E. (2009). The Terrible Simplifiers: Common Origins of Financial Crises and Persistent Poverty in Economic Theory and the New "1848 Moment." DESA Working Paper No 88, ST/ESA/2009/DWP/88, UN Department of Economic and Social Affairs. Available at: https://www.un.org/esa/desa/papers/2009/ wp88_2009.pdf (accessed 7 March 2021).

Sachs J., Schmidt-Traub G., Kroll C., Lafortune G., Fuller G., Woelm F. (2020). The Sustainable Development Goals and COVID-19. Sustainable Development Report 2020. Cambridge: Cambridge University Press. Available at:. https://doi.org/10.1017/9781108992411

Svetlichnyi A.I. (2018). Ustoychivoe razvitie i Noviy bank razvitiya BRIKS: analiz i perspektivy [Sustainable Development and BRICS New Development Bank: Analysis and Perspectives]. Public Administration Issues, no 1, pp. 68-88. Available at: https://vgmu.hse.ru/data/2018/04/05/1164630854/\%D0\%A1\%D0\%B2\%D0\% B5\%D1\%82\%D0\%BB\%D0\%B8\%D1\%87\%D0\%BD\%D1\%8B\%D0\%B9\%201-2018.pdf (accessed 7 March 2021) (in Russian).

United Nations (UN) (2018). Handbook on Duty-Free and Quota-Free Market Access and Rules of Origin for LDCs. Part II: Other Developed Countries and Developing Countries. United Nations Conference on Trade and Development (UNCTAD). Available at: https://unctad.org/en/PublicationsLibrary/aldc2018d5part2_ en.pdf (accessed 10 December 2020).

United Nations (UN) (2019). The Least Developed Countries Report. United Nations Conference on Trade and Development (UNCTAD). Available at: https://unctad.org/webflyer/least-developed-countries-report-2019 (accessed 7 March 2021).

United Nations (UN) (n. d.). Comtrade Database. Available at: https://comtrade.un.org (accessed 7 March 2021). 
Vorontsova N.A. (2018). Vsemirnaya torgovaya organizatsiya: k voprosu ob uproshchenii tamozhennykh protsedur torgovli. Chast' II [World Trade Organization: On the Facilitation of Customs Procedures for Trade. Part II]. Moscow Journal of International Law, no. 3, pp. 53-64. Available at: http://doi.org/10.24833/0869-00492018-3-53-64 (in Russian).

World Bank (n. d.). Databank: World Development Indicators. Available at: https://databank.worldbank.org/ source/world-development-indicators (accessed 7 March 2021).

World Trade Organization (WTO) (2019). Market Access for Products and Services of Export Interest to Least Developed Countries. Note by the Secretariat (WT/COMTD/LDC/W/67). Available at: https:// docs.wto.org/dol2fe/Pages/FE_Search/FE_S_S006.aspx?Query=((@Symbol=\%20wt/comtd/ldc/w/*)\%20 and $\% 20 @$ Title=\%20(market $\% 20$ access $\% 20$ for $\% 20$ products $\% 20$ and $\% 20$ services $\% 20$ of $\% 20$ export $\% 20$ interest) $\&$ Language $=$ ENGLISH\&Context $=$ FomerScriptedSearch\&languageUIChanged $=\mathrm{t} \quad($ accessed 7 March 2021).

World Trade Organization (WTO) (2020). List of Preferential Trade Arrangements. Available at: http://ptadb. wto.org/ptaList.aspx (accessed 10 December 2020). 